\title{
Visceral fat and insulin resistance - what we know?
}

\author{
Karolina Janochova ${ }^{\mathrm{a}, \mathrm{b}}$, Michal Haluzik ${ }^{\mathrm{a}}$, Marek Buzga ${ }^{\mathrm{b}}$
}

\begin{abstract}
One of the most significant challenges of current medicine is the increasing prevalence of obesity worldwide that is accompanied by a wide range of chronic health complications and increased mortality. White adipose tissue actively contributes to metabolic regulation by production of a variety of hormones and cytokines, commonly referred to as adipokines. The spectrum and quantity of adipokines produced by the adipose tissue of obese patients is directly or indirectly involved in much obesity-related pathology (type 2 diabetes mellitus, cardiovascular disease, inflammatory response). One of the underlying mechanisms linking obesity, diabetes, and cardiovascular complications is subclinical inflammation, primarily arising in visceral adipose tissue. Adipocyte size, number and polarization of lymphocytes and infiltrated macrophages are closely related to metabolic and obesity-related diseases. The storage capacity of hypertrophic adipocytes in obese patients is limited. This results in chronic energy overload and leads to increased apoptosis of adipocytes that in turn stimulates the infiltration of visceral adipose tissue by immune cells, in particular macrophages. These cells produce many proinflammatory factors; while the overall production of anti-inflammatory cytokines and adipokines is decreased. The constant release of proinflammatory factors into the circulation then contributes to a subclinical systemic inflammation, which is directly linked to the metabolic and cardiovascular complications of obesity.
\end{abstract}

Key words: adipose tissue, inflammation, insulin resistance, macrophages, obesity

Received: June 15, 2018; Accepted with revision: October 2, 2018; Available online: November 6, 2018 https://doi.org/10.5507/bp.2018.062

${ }^{a}$ Department of Chemistry, Faculty of Science, University of Ostrava, Czech Republic ${ }^{b}$ Department of Physiology, Faculty of Medicine, University of Ostrava, Czech Republic Corresponding author: Karolina Janochova, e-mail: karolina.janochova@osu.cz

\section{INTRODUCTION}

Overweight and obesity are characterized by excessive fat accumulation in the body with subsequent adverse effects on human health ${ }^{1}$. Obesity constitutes an important metabolic disease associated with the development of insulin resistance, cardiovascular diseases, type 2 diabetes mellitus, some types of cancer and may cause physical diseases ${ }^{1-3}$. Obesity, especially abdominal obesity, also plays a causative role in the pathogenesis of metabolic syndrome ${ }^{4,5}$. In 2016, more than 1.9 billion adults were overweight or obese, unfortunately, these numbers are increasing, especially in children ${ }^{1,6-8}$.

\section{ADIPOSE TISSUE DYSFUNCTION IN OBESITY}

For many years, adipose tissue was only considered a passive source of energy, which also had a thermalinsulation function and provided mechanical protection to the internal organs ${ }^{9}$. Nowadays, adipose tissue is considered an endocrine organ ${ }^{10-16}$ with immune function ${ }^{17-19}$ and it is involved in energy homeostasis regulation and food intake, energy expenditure, and many metabolic processes in the organism ${ }^{20}$. It was recently reported that the inflammation reaction in adipose tissue is an important mechanism to induce insulin resistance (IR) (ref. ${ }^{21,22}$ ).

Two basic types of adipose tissue exist, white and brown, which are histologically and functionally differentiated $^{23}$. White adipose tissue is divided into two types: sub- cutaneous and visceral (intra-abdominal). Subcutaneous adipose tissue is located under the skin and stores approximately $80 \%$ of total body fat. This type of adipose tissue is mainly found in the upper (abdominal, subscapular fat) and lower (gluteal-femoral fat) part of the body. Visceral adipose tissue is located around the internal organs and constitutes about $20 \%$ of total body fat ${ }^{24}$ and it is associated with IR, high blood pressure, high triacylglycerol levels and increased risk of diabetes and cardiovascular diseases $^{25}$. Specifically ectopic fat plays a great role in cardiovascular diseases. Ectopic fat is the storage of triacylglycerols especially in the liver, skeletal muscle, heart and pancreas (pericardial, perivascular, epicardial) and it can interfere with the cellular and organ functions and it is associated with IR and hyperinsulinemia ${ }^{26}$.

The most important part of the adipose tissue is inherent fat cells called adipocytes. Adipose tissue also contains other types of cells e.g. fibroblasts, preadipocytes, immunocompetent cells (macrophages, lymphocytes), endothelial cells ${ }^{27}$. The composition of adipose tissue changes in response to changes in the nutritional status of organisms ${ }^{28}$. Increased triacylglycerol storage in adipocytes leads to adipocyte hypertrophy (increased volumes of adipocytes) and hyperplasia (increasing number of fat cells) which significantly affects their metabolic properties e.g. insulin sensitivity or endocrine function ${ }^{29}$. Adipocytes produce substances collectively termed as adipokines (adipocytokines) which participate in the regulation of glucose and lipid metabolism, insulin sensitivity, energy homeostasis, inflammation, immunity, vascular 
function or coagulation ${ }^{30}$. The main physiological functions of selected substances secreted by adipose tissue are summarized in Table 1.

Excessive fat accumulation in obese patients leads to significant changes in the amount and function of immune cells in adipose tissue ${ }^{31}$. The amount of macrophages, mastocytes, neutrophils, T-lymphocytes, and B-lymphocytes increase and, conversely, the amount of eosinophils and some subpopulations of T-lymphocytes decrease in obese beings (Fig. 1). These changes are associated with the development of local and system inflammation ${ }^{32}$. Obesity is associated with elevated amounts of macrophages in adipose tissue ${ }^{33}$. Lean adipose tissue contains fewer than $10 \%$ of macrophages whereas in obese adipose tissue the number of macrophages is increased nearly to $40 \%$ (ref. $^{31}$ ). More than $90 \%$ of all macrophages in adipose tissue are localized near apoptic adipocytes. They are mutually interconnected and create syncytia, which trap free radicals of lipid droplets from adipocytes. They typically form multinucleated cells that represent a characteristic morphological feature of chronic inflammation $^{34}$.

Macrophages are generally classified into two phenotypes: M1 and M2 macrophages ${ }^{35}$. M1 macrophages are classically activated with a proinflammatory phenotype. The activation of M1 macrophages is mediated through c-Jun N-terminal kinase (JNK) activator protein-1 and nuclear factor- $\mathrm{kB}(\mathrm{NF}-\kappa \mathrm{B})$ signaling pathways ${ }^{3}$. M1 macrophages are activated by the proinflammatory cytokine IFN- $\gamma$ or lipopolysaccharides ${ }^{3,36}$ and secrete proinflammatory factors (TNF- $\alpha$, IL-1 $\beta$, IL-6, IL-12, IL-18, and IL-23) resulting in IR (ref. ${ }^{21,37,38}$ ). These cytokines have multiple functions, and are important mediators of inflammation in many chronic diseases including obesity and cancer ${ }^{39}$. Function of M1 macrophages is the phagocytosis and degradation of the residues of dead cells in damaged tissues as well as the elimination of microorganisms. Alternatively activated M2 macrophages are triggered by the Th2 cytokines, IL-4 and IL-13 (ref. ${ }^{40}$ ). M2 activation is mediated by the IL-4-induced activation of janus kinase and activation of signal transducer and activator of transcription signaling ${ }^{3}$. In M2 activation, several factors are involved such as peroxisome proliferation-activated receptor or enzymes like adenosine monophosphate-activated protein kinase and arginase-1, which blocks the activity of proinflammatory inducible nitric oxide synthase ${ }^{41,42}$. M2 macrophages have an anti-inflammatory phenotype characterized by low expression of proinflammatory cytokines and high expression of the anti-inflammatory cytokines (IL-10 and TGF- $\beta$ ) and the main function is to contribute to the healing and regeneration of damaged tissues ${ }^{3}$. Macrophages are capable of producing proinflammatory and anti-inflammatory factors. This is caused by the presence of both proinflammatory CD11c and anti-inflammatory CD206 on the membrane of macrophages which is used to differentiate M2 and M1 type. Macrophages are able to modify their phenotype according to the environment influences ${ }^{43}$, but the mechanisms involved in this phenotype switch are still not clear.
In obese adipose tissue the composition of immune cells is shifted and causes the inflammatory reactions in adipose tissue. There is a shift from anti-inflammatory M2 macrophages to M1 proinflammatory macrophages in obese individuals ${ }^{33,44}$. This is caused by increased attraction of circulating monocytes to adipose tissue and their differentiation into M1 cells, leading to an increase in general inflammatory markers ${ }^{33}$. On the other hand, Fjeldborg's study in 2014 found the macrophage phenotype changes in obesity with a predominance of M2 and decreasing M1 markers in subcutaneous adipose tissue ${ }^{45}$. In addition, Zeyda et al. showed that M2 macrophages can produce proinflammatory cytokines, which could contribute to systemic inflammation and the development of IR (ref. ${ }^{46}$ ). These discrepancies are may be caused by several possible reasons. Experimental data are being obtained from the different type of adipose tissue. In most studies, adipose tissue is obtained from subcutaneous depot but in other studies adipose tissue is gained from omental adipose tissue (visceral adipose tissue). Studies have shown that inflammation state determined by release of cytokines is elevated in visceral adipose tissue than in subcutaneous adipose tissue ${ }^{47}$. So this could show that the amount or macrophage phenotype differ between these types of adipose tissue. Furthermore, every patient is a special individual so also the sex and the degree of adiposity may play the key role. The last reason of discrepancies concerns the comparison of measured data in mice and humans in experimental studies. The extrapolation of data from mice to humans may be confusing because human monocytes seem to have distinct physiology from mouse monocytes ${ }^{48}$. The metabolic differences exist between rodents and human beings which can contribute to the difficulty of application mice data into human therapies.

Macrophages are the source of the elevated inflammatory cytokines and their accumulation in adipose tissue is associated with IR (ref. ${ }^{32}$ ). It has been demonstrated that weight reduction is accompanied by decreasing amount of adipose tissue macrophages ${ }^{49,50}$. The infiltration of adipose tissue by macrophages positively correlated with body mass index, the amount of body fat, adipocyte size, and the expression of proinflammatory markers (TNF- $\alpha$, IL-1 $\beta$, IL-6, IL-13, MCP-1) associated with IR in obese patients $^{51}$. It was shown that adipose tissue macrophages content is higher in visceral adipose tissue than in subcutaneous adipose tissue which agrees with the hypothesis that visceral fat plays more prominent role in IR (ref. ${ }^{50}$ ).

The amounts of classically activated M1 macrophages, Th1 $\mathrm{CD}^{+} \mathrm{T}$ cells, CD ${ }^{+} \mathrm{T}$ cells, mast cells, B cells, and neutrophils are increased in obese individuals. Obesity decreases the expression of anti-inflammatory factors and increases the expression of the proinflammatory antigens (F4/80, CD11b - integrin alpha M, CD11c - integrin alpha $\mathrm{X}$ ) and proinflammatory cytokines (TNF- $\alpha$, IL6 , inducible nitric oxide synthase) in adipose tissue. In comparison with lean individuals, the levels of TNF- $\alpha$, IL-6, IL-1 $\beta$, MCP-1 and PAI-1 are increased mainly in obese visceral fat. The levels of leptin are also increased in obese beings and correlate with the percentage of body 
Table 1. Physiological functions of selected substances secreted by white adipose tissue.

\begin{tabular}{|c|c|c|c|c|c|c|c|}
\hline \multirow[t]{2}{*}{ Adipokines } & \multicolumn{7}{|c|}{ Physiological function } \\
\hline & 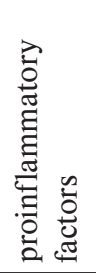 & 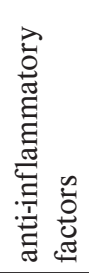 & 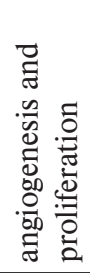 & 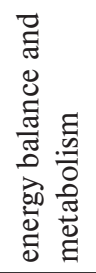 & 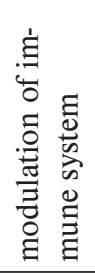 & 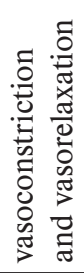 & 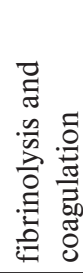 \\
\hline Adiponectin & & $\bullet$ & $\bullet$ & $\bullet$ & & $\bullet$ & \\
\hline Adipsin & $\bullet$ & & & $\bullet$ & $\bullet$ & & \\
\hline Angiopoietin 1 and 2 & & & $\bullet$ & & & & \\
\hline ANGPTL4 & & & & $\bullet$ & $\bullet$ & & \\
\hline Angiotensin II & $\bullet$ & & $\bullet$ & $\bullet$ & & $\bullet$ & \\
\hline Apelin & $\bullet$ & & & $\bullet$ & & & \\
\hline DAP IV & $\bullet$ & & & $\bullet$ & & & \\
\hline $\begin{array}{l}\text { growth factors (TGF- } \beta, F G F, \text { HGF, } \\
\text { IGF-1, NGF, VEGF) }\end{array}$ & & & $\bullet$ & & & & \\
\hline IL-1 $\beta$ & $\bullet$ & & & & & & \\
\hline IL-4 & & $\bullet$ & & & & & \\
\hline IL-6 & $\bullet$ & & & $\bullet$ & $\bullet$ & & \\
\hline IL-10 & & $\bullet$ & & & $\bullet$ & & \\
\hline IL-13 & & • & & & & & \\
\hline Leptin & & & • & $\bullet$ & $\bullet$ & $\bullet$ & $\bullet$ \\
\hline Lipocalin 2 & $\bullet$ & & & $\bullet$ & & & \\
\hline Lipoprotein lipase & & & & • & & & \\
\hline MCP-1 (CCL2) & $\bullet$ & & & & $\bullet$ & & \\
\hline MIF & $\bullet$ & & & & $\bullet$ & & \\
\hline Omentin & & - ? & & $\bullet$ & & $\bullet$ & \\
\hline PAI-1 & & & & & & & $\bullet$ \\
\hline RBP4 & & & & • & & & \\
\hline Resistin & $\bullet$ & & & $\bullet$ & $\bullet$ & $\bullet$ & \\
\hline TNF- $\alpha$ & $\bullet$ & & & $\bullet$ & & & \\
\hline Visfatin & & & & $\bullet$ & & $\bullet$ & \\
\hline
\end{tabular}

ANGPTL4 - angiopoietin-like 4, DAP IV - dipeptidyl aminopeptidase IV, FGF - fibroblast growth factor, HGF - hepatocyte growth factor, IGF-1 - insulin-like growth factor 1, IL - interleukins, MCP-1 - monocyte chemotactic protein 1, MIF - macrophage migration inhibitory factor, NGF - nerve growth factor, PAI-1 - plasminogen activator inhibitor 1, RBP4 - retinol binding protein 4, TGF- $\beta$ - transforming growth factor beta, TNF- $\alpha$ - tumor necrosis factor alpha, VEGF - vascular endothelial growth factor

fat. On the other hand, the adiponectin plasma levels are lower in obese individuals. Alternatively, activated $\mathrm{M} 2$ macrophages, Th2 $\mathrm{CD}^{+} \mathrm{T}$ cells, regulatory $\mathrm{CD}^{+}$ cells, eosinophils, and iNKT cells are the dominant immune cells in the adipose tissue of lean individuals. The M2 macrophages express antigens like CD163, CD206, CD209, and CD301 and produce anti-inflammatory cytokines (IL-1Ra, IL-4, IL-10, IL-13) and arginase 1, which suppress the inflammation, maintain insulin sensitivity, and improve insulin signaling with a protective role in obesity-induced IR.

\section{LINKS BETWEEN OBESITY AND SUBCLINICAL INFLAMMATION}

According to evidences of studies, inflammation in adipose tissue may play a critical role in the development of obesity-related metabolic dysfunction ${ }^{11,52-54}$. Inflammation initiates and further contributes to adipose tissue remodeling which includes adipose tissue hypertrophy ${ }^{55}$, infiltration of adipose tissue by immune cells ${ }^{32}$, angiogenesis and fibrosis $^{56}$, oxidative stress ${ }^{57}$ and hypoxia ${ }^{58}$. Many clinical studies have dealt with the subclinical inflammation hypothesis in adipose tissue in obese patients ${ }^{21,22,59}$. Obesity have been already evaluated as a state of chronical inflammation, which is indicated by elevated levels of C-reactive protein (CRP) $\left(\right.$ ref. $\left.^{60}\right)$, IL-6 (ref. ${ }^{61}$ ), PAI-1 (ref. ${ }^{62}$ ), MCP-1 $\left(\right.$ ref. $\left.{ }^{63}\right)$ and TNF- $\alpha\left(\right.$ ref. $\left.^{64}\right)$. The adipocytes of obese individuals are continually overloaded by triacylglycerols and subsequently, maximum capacity of adipocytes is constantly exceeded in terms of triacylglycerol storing, leading to their increased apoptosis. This, in turn, stimulates macrophage infiltration in adipose tissue $\mathrm{e}^{32,65}$. The interaction between immune cells and adipocytes leads to adipocyte dysfunction with excessive release of proinflammatory factors into the circulation.

Excessive food intake initiates adipocyte hypertrophy 


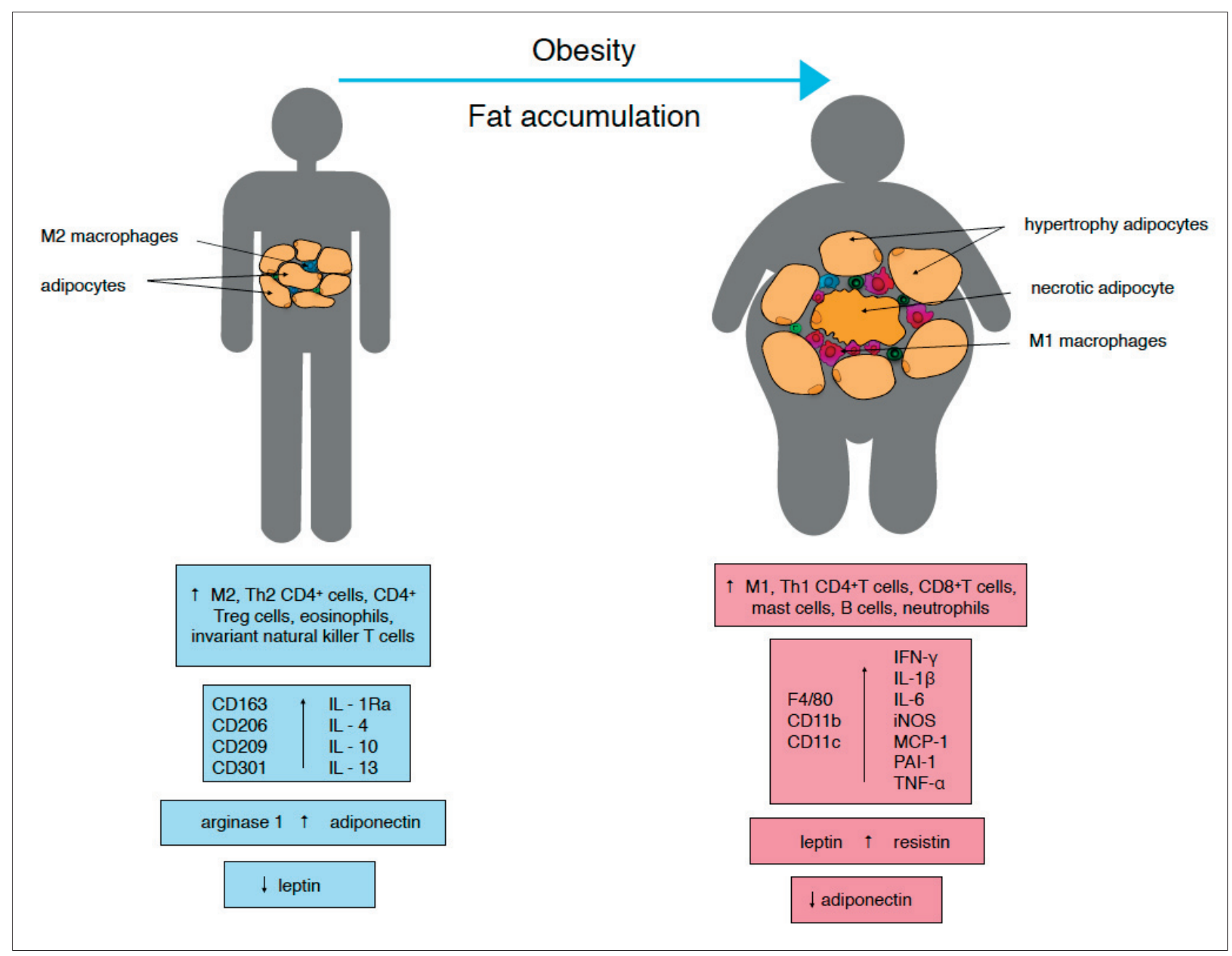

Fig. 1. The comparison of substances released by lean vs. obese individuals. (CD - cluster of differentiation, IFN- $\gamma$ - interferon $\gamma$, IL - interleukins, iNOS - inducible nitric oxide synthase, MCP-1 - monocyte chemotactic protein 1, PAI-1 - plasminogen activator inhibitor 1 , TGF- $\beta$ - transforming growth factor beta, Th 1 - type 1 T helper cells, Th2 - type $2 \mathrm{~T}$ helper cells, Treg cells - regulatory T cells, TNF- $\alpha$ - tumor necrosis factor alpha)

and hyperplasia resulting in cellular stress in adipocytes; this initiates oxidative stress and inflammatory responses in adipose tissue and amplifies the systemic inflammation response ${ }^{21,66-68}$. Hyperlipidemia, hyperglycemia, lipolysis, and gluconeogenesis negatively affect the function of mitochondria and initiate oxidative stress ${ }^{21,22}$. This oxidative stress forms as a result of an imbalance between the productions of reactive oxygen species and anti-oxidative defensive mechanisms against reactive oxygen species in adipose tissue. The adipose tissue of lean individuals expresses antioxidant enzymes (superoxide dismutase-1, catalase, glutathione peroxidase) for the management of reactive oxygen species production and these expressions are suppressed and reduced in the adipose tissue of obese individuals. The stress-signaling JNK, inhibitor of kappa $\beta$ kinase (IKK- $\beta$ ), and the transcriptional-mediated $\mathrm{NF}-\kappa \mathrm{B}$ pathways are involved in the imbalance between reactive oxygen species and antioxidants ${ }^{22,66}$. The activation of these pathways stimulates the proinflammatory response, significantly contributes to IR development ${ }^{69}$, and causes oxidative and endoplasmic reticulum stress ${ }^{22}$. The JNK and NF-kB pathways decrease the glucose up- take mediated by insulin and insulin signaling, inducing IR (Fig. 2) ( ref. $^{70}$ ). Moreover, the activation of the NF-кB pathway may be associated with endothelial dysfunction, leading to the induction of IR; thus, anti-oxidant therapy may prevent the induction of IR (ref. ${ }^{22,71}$ ). Some type 2 diabetes mellitus treatments modulated endoplasmic reticulum stress, possibly indicating a new therapeutic target for treating IR ( ref. $^{22}$ ).

The activation of the proinflammatory state may interfere with the intracellular signal transduction mediated by insulin in several ways, causing systemic IR (ref. ${ }^{65,72}$ ). It may lead to decreasing glucose transporter type 4 (GLUT4) and insulin receptor substrate 1 (IRS-1) expression. It may cause the induction of cytokines that sterically block the binding of insulin receptor with IRS-1. It may also initiate the phosphorylation of serine residues on IRS-1 that block the tyrosine phosphorylation of this regulatory protein, negatively affecting the reaction to insulin ${ }^{65}$. Obesity is associated with the infiltration of macrophages into adipose tissue. Macrophages produce factors that block the action of insulin in adipocytes by reducing GLUT-4 and IRS-1 expression and attenuate in- 


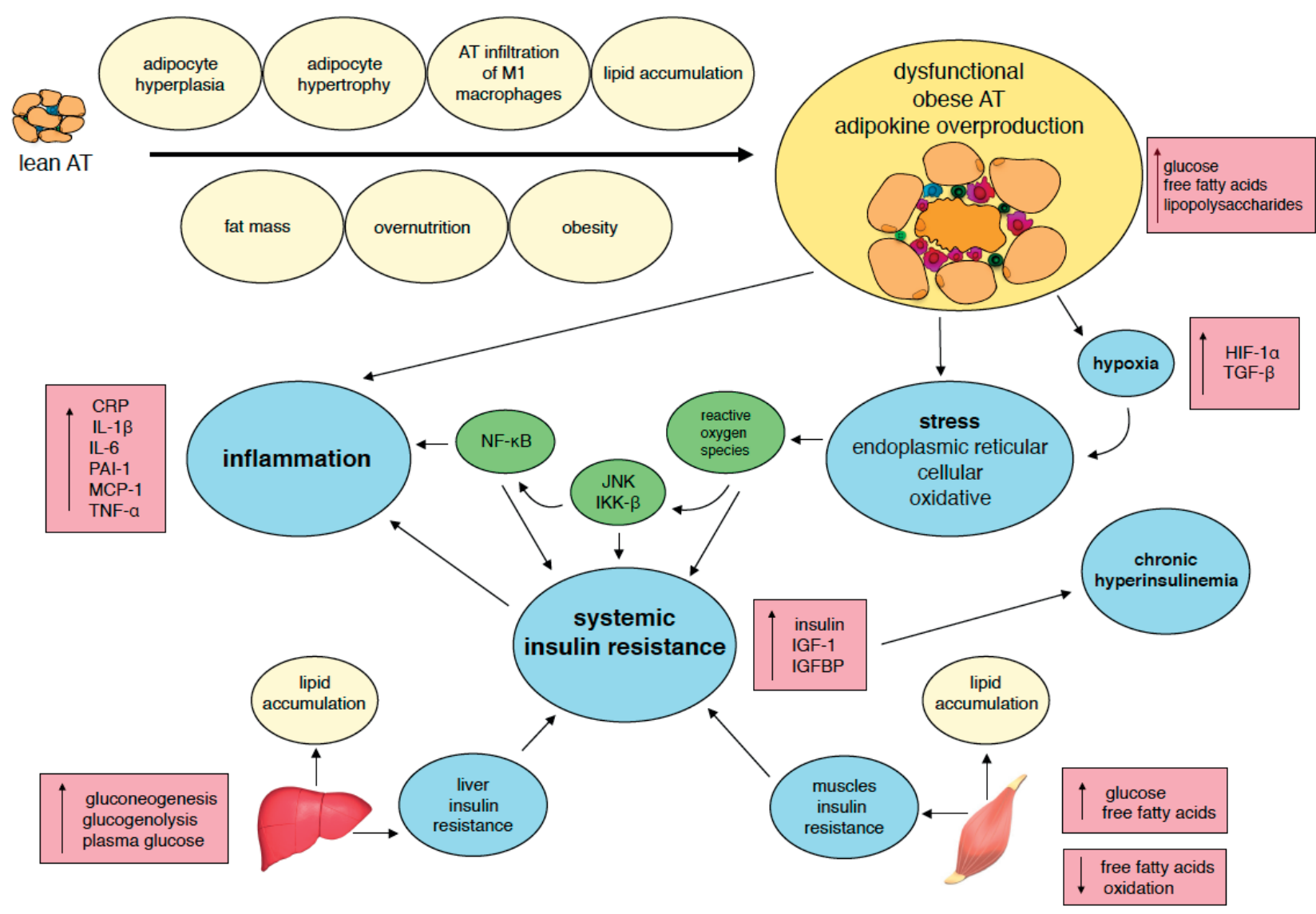

Fig. 2. Relationships among inflammation, insulin resistance (IR), and stress in adipose tissue.

(AT - adipose tissue, CRP - C-reactive protein, IGF-1, insulin growth factor 1, IGFBP - insulin growth factor binding protein, IKK- $\beta$ - IkB kinase $\beta$ pathway, IL - interleukins, JNK - c-JUN N-terminal kinase pathway, MCP-1 - monocyte chemotactic protein 1, NF-kB - nuclear factor-kb, pathway, PAI-1 - plasminogen activator inhibitor 1, TGF- $\beta$ - transforming growth factor beta, TNF- $\alpha$ - tumor necrosis factor alpha)

sulin-stimulated translocation of GLUT-4 on the plasma membrane ${ }^{73}$. Increasing concentrations of the proinflammatory cytokines, TNF- $\alpha$ and IL- 6 , may affect insulin action by suppressing or interrupting a signal transduction mediated by insulin and distort its anti-inflammatory effect, promoting the inflammation reaction ${ }^{65}$. The first adipose-derived factor suggested representing a link between obesity, inflammation and diabetes was TNF- $\alpha$. This assumption was confirmed by the later works which showed a positive correlation between increased TNF- $\alpha$ concentration in human adipocytes and degree of obesity, insulin levels and IR (ref. ${ }^{74}$ ). But it was recognized that the adipocytes are not the major source of TNF- $\alpha$. The main source of adipose-derived TNF- $\alpha$ is the macrophages from stromal vascular fraction and due to the macrophage infiltration into adipose tissue plasma levels of TNF- $\alpha$ increase in obese individuals ${ }^{31,64}$. TNF- $\alpha$ together with IL-6 can attenuate IR by sterically preventing the binding of the insulin receptor with IRS-1 (ref. ${ }^{75}$ ), increasing lipolysis and levels of free fatty acids in serum. Proinflammatory factors induce activation of mitogen-activated protein kinase and transcription factors (NF- $\mathrm{kB}$ ) affecting GLUT4 and IRS-1, blocking the action of insulin and cause IR $\left(\right.$ ref. $\left.^{76}\right)$. In many cases, depression and stress lead to weight gain associated with the accumulation of fat cells, where the proinflammatory response is induced by the release of IL-6. Elevated levels of IL-6 in circulation were connected with stress; thus, IL-6 may be responsible for inducing a systemic inflammation reaction ${ }^{77}$. IL-6 has a lipolytic effect with a consequent increase of free fatty acids levels in circulation. IL-6 inhibits insulin signaling cascade leading to the impairment of insulin-induced insulin receptor and IRS-1 phosphorylation ${ }^{74}$. Saturated free fatty acids and lipopolysaccharides bind to the Toll-like receptor 4 and stimulate cytokine production of macrophages and the production of proinflammatory factors ${ }^{78}$ thereby modulating the inflammation of adipose tissue which contributes to obesity-associated metabolic complications. Toll-like receptor 4 regulates insulin sensitivity and also inhibits insulin action and signal transduction through serine phosphorylation of IRS-1 and activation of proinflammatory factors and reactive oxygen species ${ }^{22}$. However, the concentrations of circulating free fatty acids do not increase in portion to fat mass and do not predict the development of metabolic syndrome ${ }^{79}$ although many studies suggest the relationship between the release of free fatty acids from adipose tissue and obesity-related disorders ${ }^{78,80}$.

Overnutrition, fat mass, and lipid accumulation lead to obesity, adipocyte hypertrophy, and hyperplasia and 
increase M1 macrophage infiltration to adipose tissue. This leads to dysfunctional obese adipose tissue, which is characterized by the hypersecretion of adipokines. In adipose tissue of obese beings, the levels of glucose, free fatty acids, and lipopolysaccharides increase. The release of free fatty acids from adipocytes into the circulation can contribute to the initiation and progression of metabolic complications induced in obesity and may be a critical factor in modulating insulin sensitivity. Dysfunction of obese adipose tissue is associated with hypoxia, ERS, oxidative and cellular stress, inflammation, and IR. The activations of JNK, IKK- $\beta$, and NF- $\mathrm{kB}$ pathways are caused by oxidative stress and endoplasmic reticular stress and are associated with the oversecretion of proinflammatory factors, such as TNF- $\alpha$, IL-6, MCP-1, PAI-1, and IL-1 $\beta$. Adipose tissue may affect other tissues (liver, muscle, heart) through the production of proinflammatory factors and free fatty acids and it leads to the systemic IR.

\section{CONCLUSIONS AND FUTURE DIRECTIONS}

Obesity is viewed as a state of systemic, chronic, lowgrade inflammation ${ }^{31,32}$. The inflammation reactions in adipose tissue are causally linked to obesity and the development of IR ( ref. $^{81}$ ). Long-term, the etiopathogenetic factor of obesity is very important in the formation of metabolic complications including type 2 diabetes mellitus, metabolic syndrome, dysglycemia, dyslipidemia, and hypertension. The combination of these diseases significantly increases cardiovascular morbidity and mortality in obese patients.

Increased subcutaneous adipose tissue is associated with a reduced risk of obesity-induced metabolic dysregulation and enhanced insulin sensitivity, thus the accumulation of subcutaneous adipose tissue (especially in the thighs, hips and buttocks) may be propose to be protective compared with the harmful consequences of visceral adiposity $^{82}$. So the mechanisms that determine the size and expandability of subcutaneous adipose tissue may be important targets for future therapy. Deeper understanding how adipose tissue distribution is regulated may lead to novel therapeutic treatments of obesity ${ }^{29}$.

Obesity is characterized by increasing fat cell numbers and fat cell size ${ }^{83}$. This fact leads to the unbalance of proinflammatory and anti-inflammatory factors secreted by adipose tissue. Dysregulation of proinflammatory and anti-inflammatory adipokines contributes to the development of metabolic and cardiovascular disorders. It is proved that weight loss improves inflammatory status in obesity and its comorbidities by decreasing numbers of inflammatory factors ${ }^{84,85}$. In the obese state, adipose tissue is infiltrated by M1 macrophages that release many proinflammatory factors (e.g. TNF- $\alpha$, IL-6), thus linking obesity, inflammation and IR $\left(\right.$ ref. $\left.^{20}\right)$. A shift towards the M2 anti-inflammatory profile may be a protective mechanism to suppress inflammation in obese adipose tissue thus this will open potential pharmacological treatment strategies in metabolic abnormalities associated with obesity.
Many various approaches have been examined to inhibit inflammatory responses by neutralizing the cytokines, chemokines, adhesion molecules or other mediators $^{86}$. It was shown that plasma levels of inflammatory markers can be reduced by blocking TNF- $\alpha$ and other studies have demonstrated that intervention of TNF- $\alpha$ antagonist results in reduced blood glucose levels and increased adiponectin levels ${ }^{87,88}$. The inhibition of IKK- $\beta$ and NF- $\kappa$ B pathways may suppress the activation or production of proinflammatory cytokines. It is important to understand the actions of the signaling pathways through which adipokines control metabolism and try to discover new therapies for diseases related to adipose tissue ${ }^{20}$. The identification of the mechanisms inducing the inflammation reactions and the analysis of the immune cells involved in this process could contribute to new treatment strategies for metabolic complications of obesity.

It is demonstrated that leptin levels positively correlate with body fat in obese beings and decrease in lean individuals ${ }^{89}$, numerous clinical trials have been based on the use of recombinant leptin for weight reduction but this has only led to a slight weight reduction ${ }^{90}$. Nowadays, recombinant leptin is used to treat monogenic obesity caused by leptin mutation that leads to leptin deficiency ${ }^{91}$. Further research of the mechanisms of adipose tissue released substances may lead to the better understanding of the development of obesity-related metabolic syndrome.

Nowadays, there are many ways to treat obesity. Conservative (non-surgical) approaches or surgical bariatric procedures exist. Conservative treatment is complex therapy including cognitive behavioral therapy, diet therapy and nutritional education, increased physical activity and pharmacotherapy. The aim of modern drug therapy should be to correct the metabolic disorders underlying the development of obesity and associated health complications thus helping the long-term success of reduction mode. At present, only a limited number of medicines is available for the obesity treatment for which a long-term efficiency and safety have been demonstrated in long-term clinical studies. In case of failure of conservative treatment or after a jojo effect after its termination, surgical treatment of obesity can be considered. For a bariatric surgery body mass index value must be over 40, or in the case of serious obesity-related comorbidities at least over 35. Surgical options for obesity treatment have become one of the most basic practices in the last 15 years that offer long-term, permanent and significant weight loss, especially in grave forms of obesity. Bariatric surgery has proven to be the most effective and long-lasting way of treating patients with the second degree of obesity and some with obesity-related disorders or with the third degree of obesity without other comorbidities ${ }^{92}$.

Although, the best way to mitigate the metabolic complications of obesity are to increase physical activity and reduce body weight and fat mass because it is documented that exercise attenuate obesity induced expression of inflammatory adipokines secretes by white adipose tissue ${ }^{93}$ and overall physical activity has a positive effects on the subclinical inflammation in obesity ${ }^{94}$. 


\section{Search strategy and selection criteria}

Articles and studies were searched using the Web of Science and PubMed databases. Only English papers were reviewed. The search terms used included "adipose tissue", "adipokines", "macrophages", "inflammation in obese patients" and "proinflammatory factors in obese individuals".

Acknowledgement: This article was derived from a grant (IRP no. 20154) in the Department of Physiology, Ostrava, Czech Republic.

Author contributions: All authors contributed in writing the manuscript and read and approved the final manuscript.

Conflicts of interest statement: The authors declare that they have no competing interests.

\section{REFERENCES}

1. World health organisation. World health organisation. [online] 24.1.2017 [cited 2017-01-24]. Available from: http://www.who.int/ en/

2. Adamczak $M$, Wiecek $A$. The adipose tissue as an endocrine organ. Semin Nephrol 2013;33:2-13.

3. Pérez-Hernández A, Catalán V, Gómez-Ambrosi J, Rodríguez A, Frühbeck $G$. Mechanisms linking excess adiposity and carcinogenesis promotion. Front Endocrinol 2014;5:1-17.

4. Maury E, Brichard SM. Adipokine dysregulation, adipose tissue inflammation and metabolic syndrome. Mol Cell Endocrino 2010;314:1-16

5. Després JP, Lemieux I, Bergeron J, Pibarot P, Mathieu P, Larose E, Rodés-Cabau J, Bertrand OF, Poirier P. Abdominal obesity and the metabolic syndrome: contribution to global cardiometabolic risk. Arterioscler Thromb Vasc Biol 2008;28:1039-49.

6. Deckelbaum RJ, Williams CL. Childhood obesity: The health issue. Obes Res 2001;9:239-43.

7. Spiegelman BM, Flier JS. Obesity and the regulation of energy balance. Cell 2001;104:531-43.

8. Lobstein T, Baur L, Uauy R. Obesity in children and young people: a crisis in public health. Obes Rev 2004;5:4-85.

9. Smitka K, Maresova D. Adipose tissue as an endocrine organ: An update on pro-inflammatory and anti-inflammatory microenvironment. Prague Med Rep 2015;116:87-111.

10. Galic S, Oakhill JS, Steinberg GR. Adipose tissue as an endocrine organ. Mol Cell Endocrinol 2010;316:129-39.

11. Ahima RS, Flier JS. Adipose tissue as an endocrine organ. Trends Endocrinol Metab 2000;11:327-32.

12. Trayhurn $\mathrm{P}$, Beattie JH. Physiological role of adipose tissue: white adipose tissue as an endocrine and secretory organ Proc Nutr Soc. 2001;60:329-39.

13. Prins JB. Adipose tissue as an endocrine organ. Best Prac Res Clin Endocrinol Metab 2002;16:639-51.

14. Kershaw EE, Flier JS. Adipose tissue as an endocrine organ. J Clin Endocrinol Metab 2004;89:2548-56.

15. Ronti T, Lupattelli G, Mannariho $E$. The endocrine function of adipose tissue: an update. Clin 2006;64:355-65.

16. Fonseca-Alaniz MH, Takada J, Alonso-Vale MI, Lima FB. Adipose tissue as an endocrine organ: from theory to practice. J Pediatr 2007;83:192-203.

17. Pond CM. Adipose tissue and the immune system. Prostaglandins Leukot Essent Fatty Acids 2005;73:17-30.

18. Schipper HS, Prakken B, Kalkhoven E, Boes M. Adipose-tissue resident immune cells: key players in immunometabolism. Trends Endocrinol Metab 2012;23:407-15.

19. Mráz M, Haluzík M. The role of adipose tissue immune cells in obesity and low-grade inflammation. J Endocrinol 2014;222:113-27.

20. Coelho M, Oliveira T, Fernandes R. Biochemistry of adipose tissue: an endocrine organ. Arch Med Sci 2012;9:191-200.
21. Kwon $\mathrm{H}$, Pessin JE. Adipokines mediate inflammation and insulin resistance. Front Endocrinol (Lausanne) 2013;4:1-13.

22. Rehman K, Akash MS. Mechanisms of inflammatory responses and development of insulin resistance: how are they interlinked? J Biomed Sci 2016;23:1-18.

23. Berry DC, Stenesen D, Zeve D, Graff JM. The developmental origins of adipose tissue. Development 2013;140:3939-49.

24. Tsiloulis T, Wat JM. Exercise and the Regulation of Adipose Tissue Metabolism. Prog Mol Biol Transl Sci 2015;135:175-201.

25. Després JP. Cardiovascular disease under the influence of excess visceral fat. Crit Pathw Cardiol 2007;6:51-9.

26. Després JP, Lemieux I, Bergeron J, Pibarot $P$, Mathieu P, Larose E, Rodés-Cabau J, Bertrand OF, Poirier P. Abdominal obesity and the metabolic syndrome: contribution to global cardiometabolic risk. Arterioscler Thromb Vasc Biol 2008 Jun;28:1039-49.

27. Wozniak SE, Gee LL, Wachtel MS, Frezza EE. Adipose tissue: The new endocrine organ? A review article. Dig Dis Sci 2009;54:1847-56.

28. Choe SS, Huh JY, Hwang IJ, Kim JI, Kim JB. Adipose Tissue Remodeling: Its Role in Energy Metabolism and Metabolic Disorders. Front Endocrinol (Lausanne) 2016;7:1-16.

29. Gupta RK. Adipocytes. Curr Biol 2014;24:R988-R93.

30. RomachoT, Sánchez-Ferrer CF, Peiró C. Visfatin/Nampt: an adipokine with cardiovascular impact. Mediators Inflamm 2013;2013:1-15.

31. Weisberg SP, McCann D, Desai M, Rosenbaum M, Leibel RL, Ferrante AW. Obesity is associated with macrophage accumulation in adipose tissue. J Clin Invest 2003;112:1796-1808.

32. Cildir G, Akincilar SC, Tergaonkar V. Chronic adipose tissue inflammation: all immune cells on the stage. Trends Mol Med 2013;19:487500.

33. Lumeng CN, Bodzin JL, Saltiel AR. Obesity induces a phenotypic switch in adipose tissue macrophage polarization. J Clin Invest 2007;117:175-84

34. Cinti S, Mitchell G, Barbatelli G, Murano I, Ceresi E, Faloia E, Wang S, Fortier M, Greenberg AS, Obin MS. Adipocyte death defines macrophage localization and function in adipose tissue of obese mice and humans. J Lipid Res 2005;46:2347-55.

35. Mills CD, Kincaid K, Alt JM, Heilman MJ, Hill AM. M-1/M-2 macrophages and the Th1/Th2 paradigm, J Immunol 2000;164:6166-73.

36. Mantovani A, Sica A, Sozzani S, Allavena P, Vecchi A, Locati M. The chemokine system in diverse forms of macrophage activation and polarization. Trends Immunol 2004;25:677-86.

37. Moser DM, Edwards JP. Exploring the full spectrum of macrophage activation. Nat Rev Immunol 2008;8:958-69.

38. Luzina IG, Keegan AD, Heller NM, Rook GA, Shea-Donohue T, Atamas SP. Regulation of inflammation by interleukin-4: a review of "alternatives". J Leukoc Biol 2012;4:753-64.

39. Murray PJ, Wynn TA. Protective and pathogenic functions of macrophage subsets. Nat Rev Immunol 2011;11:723-37.

40. Gordon S. Macrophage heterogeneity and tissue lipids. J Clin Invest 2007; 1:89-93.

41. Chawla A, Nguyen KD, Goh YP. Macrophage-mediated inflammation in metabolic disease. Nat Rev Immunol 2011;11:738-49.

42. Lee BC, Lee J. Cellular and molecular players in adipose tissue inflammation in the development of obesity-induced insulin resistance. Biochim Biophys Acta 2014;1842:446-62.

43. Stout RD, Jiang C, Matta B, Tietzel I, Watkins SK, Suttles J. Macrophages sequentially change their functional phenotype in response to changes in microenvironmental influences. J Immunol 2005; 175:342-49.

44. Bourlier V, Zakaroff-Girard A, Miranville A, De Barros S, Maumus M, Sengenes C, Galitzky J, Lafontan M, Karpe F, Frayn KN, Bouloumié A. Remodeling phenotype of human subcutaneous adipose tissue macrophages. Circulation 2008;117:806-15.

45. Fjeldborg K, Pedersen S.B., Møller HJ, Christiansen T, Bennetzen M, Richelsen B. Human adipose tissue macrophages are enhanced but changed to an anti-inflammatory profile in obesity. J Immunol Res 2014;2014:1-11.

46. Zeyda M, Farmer D, Todoric J, Aszmann O, Speiser M, Györi G, Zlabinger GJ, Stulnig TM. Human adipose tissue macrophages are of an anti-inflammatory phenotype but capable of excessive proinflammatory mediator production. Int J Obes (Lond) 2007;31:142028

47. Cartier A, Lemieux I, Alméras N, Tremblay A, Bergeron J, Després JP. Visceral obesity and plasma glucose-insulin homeostasis: contribu- 
tions of interleukin- 6 and tumor necrosis factor-alpha in men. J Clin Endocrinol Metab 2008;5:1931-38.

48. Strauss-Ayali D, Conrad SM, Mosser DM. Monocyte subpopulations and their differentiation patterns during infection. J Leukoc Biolog 2007;2:244-52.

49. Cancello R, Henegar C, Viguerie N, Taleb S, Poitou C, Rouault C, Coupaye M, Pelloux V, Hugol D, Bouillot JL, Bouloumié A, Barbatelli G, Cinti S, Svensson PA, Barsh GS, Zucker JD, Basdevant A, Langin $D$, Clément K. Reduction of macrophage infiltration and chemoattractant gene expression changes in white adipose tissue of morbidly obese subjects after surgery-induced weight loss. Diabetes 2005;54:2277-86.

50. Cancello R, Tordjman J, Poitou C, Guilhem G, Bouillot JL, Hugol D, Coussieu C, Basdevant A, Bar Hen A, Bedossa P, Guerre-Millo M, Clément $\mathrm{K}$. Increased infiltration of macrophages in omental adipose tissue is associated with marked hepatic lesions in morbid human obesity. Diabetes 2006;55:1554-61.

51. Apovian CM, Bigornia S, Mott M, Meyers MR, Ulloor J, Gagua M, McDonnell M, Hess D, Joseph L, Gokce N. Adipose macrophage infiltration is associated with insulin resistance and vascular endothelial dysfunction in obese subjects. Arterioscler Throm Vasc Bio 2008;28:1654-59.

52. Lumeng CN, Saltiel AR. Inflammatory links between obesity and metabolic disease. J Clin Invest 2011;121:2111-17.

53. Hotamisligil GS. Inflammation and metabolic disorders. Nature 2006;444:860-67.

54. Catalán V, Goméz-Ambrosi J, Rodríguez A, Frühbeck G. Role of extracellular matrix remodelling in adipose tissue pathophysiology: relevance in the development of obesity. Histol Histopatho 2012;27:1515-28.

55. Medzhitov R. Origin and physiological roles of inflammation. Nature 2008;454:428-35.

56. Divoux A, Tordjman J, Lacasa D, Veyrie N, Hugol D, Aissat A, Basdevant A, Guerre-Millo M, Poitou C, Zucker JD, Bedossa P, Clément K. Fibrosis in human adipose tissue: composition, distribution, and link with lipid metabolism and fat mass loss. Diabetes 2010;59:2817-25.

57. Furukawa S, Fujita T, Shimabukuro M, Iwaki M, Yamada Y, Nakajima Y, Nakayama O, Makishima M, Matsuda M, Shimomura I. Increased oxidative stress in obesity and its impact on metabolic syndrome. J Clin Invest 2004;114:1752-61.

58. Trayhurn P. Hypoxia and adipose tissue function and dysfunction in obesity. Physiol Rev 2013;93:1-21.

59. Tataranni PA. Relationship between subclinical inflammation, obesity, diabetes and related disorders. Drug Discov Today Dis Mech 2005;2:303-6.

60. Visser M, Bouter LM, McQuillan GM, Wener MH, Harris TB. Elevated C-reactive protein levels in overweight and obese adults. JAMA 1999;282:2131-35.

61. Roytblat L, Rachinsky M, Fisher A. Raised interleukin-6 levels in obese patients. Obes Res 2000;8:673-75.

62. Alessi MC, Peiretti F, Morange P, Henry M, Nalbone G, Juhan-Vague I. Production of plasminogen activator inhibitor 1 by human adipose tissue: possible link between visceral fat accumulation and vascular disease, Diabetes 1997;46:860-7.

63. Sartipy P, Loskutoff DJ. Monocyte chemoattractant protein 1 in obesity and insulin resistance Proc Natl Acad Sci USA 2003;100:7265-70.

64. Hotamisligil GS, Arner P, Caro JF, Atkinson RL, Spiegelman BM. Increased adipose tissue expression of tumor necrosis factor-alpha in human obesity and insulin resistance. J Clin Invest 1995;95:240915.

65. Oliver E, McGillicuddy F, Phillips C, Toomey S, Roche HM. The role of inflammation and macrophage accumulation in the development of obesity-induced type 2 diabetes mellitus and the possible therapeutic effects of long-chain n-3 PUFA. Proc Nutr Soc 2010;69:232-43.

66. Keaney JF, Larson MG, Vasan RS, Wilson PW, Lipinska I, Corey D, Massaro JM, Sutherland P, Vita JA, Benjamin EJ; Framingham Study. Obesity and systemic oxidative stress: clinical correlates of oxidative stress in the Framingham Study. Arterioscler Thromb Vasc Bio 2003;23:434-39.

67. Bjørklund $\mathrm{G}$, Chirumbolo $\mathrm{S}$. Role of oxidative stress and antioxidants in daily nutrition and human health. Nutrition 2017;33:311-21.

68. Muñoz A, Costa M. Nutritionally mediated oxidative stress and inflammation. Oxid Med Cell Longev 2013;2013:1-10.

69. Shi H, Kokoeva MV, Inouye K, Tzameli I, Yin H, Flier JS. TLR4 links in- nate immunity and fatty acid-induced insulin resistance. J Clin Invest 2006;116:3015-25.

70. Hirosumi J, Tuncman G, Chang L, Görgün CZ, Uysal KT, Maeda K, Karin M, Hotamisligil GS. A central role for JNK in obesity and insulin resistance. Nature 2002;420:333-36.

71. Arcaro G, Cretti A, Balzano S, Lechi A, Muggeo M, Bonora E, Bonadonna RC. Insulin causes endothelial dysfunction in humans: sites and mechanisms. Circulation 2002;105:576-82.

72. Fernández-Sánchez A, Madrigal-Santillán E, Bautista M, EsquivelSoto J, Morales-González A, Esquivel-Chirino C, DuranteMontiel I, Sánchez-Rivera G, Valadez-Vega C, Morales-González JA. Inflammation, oxidative stress and obesity. Int J Mol Sci 2011;12:3117-32.

73. Lumeng CN, Deyoung SM, Saltiel AR. Macrophages block insulin action in adipocytes by altering expression of signaling and glucose transport proteins. Am J Physiol Endocrinol Metab 2007;292:166-74.

74. Kern PA, Ranganathan S, Li C, Wood L, Ranganathan G. Adipose tissue tumor necrosis factor and interleukin- 6 expression in human obesity and insulin resistance. Am J Physiol Endocrinol Metab 2001;280:E745-51.

75. Hotamisligil GS, Peraldi P, Budavari A, Ellis R, White MF, Spiegelman BM. IRS-1-mediated inhibition of insulin receptor tyrosine kinase activity in TNF-alpha and obesity-induced insulin resistance. Science 1996;271:665-8.

76. Zhang HH, Halbleib M, Ahmad F, Manganiello VC, Greenberg AS. Tumor necrosis factor-alpha stimulates lipolysis in differentiated human adipocytes through activation of extracellular signal-related kinase and elevation of intracellular CAMP. Diabetes 2002;51:292935.

77. Kiecolt-Glaser JK, Preacher KJ, MacCallum RC, Atkinson C, Malarkey WB, Glaser R. Chronic stress and age-related increases in the proinflammatory cytokine IL-6. Proc Natl Acad Sci USA 2003;100:9090-5.

78. Suganami T, Nishida J, Ogawa Y. A paracrine loop between adipocytes and macrophages aggravates inflammatory changes: Role of free fatty acids and tumor necrosis factor alpha. Arterioscler Thromb Vasc Biol 2005;25:2062-8.

79. Byrne CD, Maison P, Halsall D, Martensz N, Hales CN, Wareham NJ. Cross-sectional but not longitudinal associations between non-esterified fatty acid levels and glucose intolerance and other features of the metabolic syndrome. Diabet Med 1999;16:1007-15.

80. Boden G. Obesity and free fatty acids. Endocrinol Metab Clin North Am 2008;37:635-46.

81. Shoelson SE, Lee J, Goldfine AB. Inflammation and insulin resistance. J Clin Invest 2006;116:1793-801.

82. Booth A, Magnuson A, Foster M. Detrimental and protective fat body fat distribution and its relation to metabolic disease. Horm Mol Biol Clin Investig 2014;7:13-27.

83. Garaulet M, Hernandez-Morante JJ, Lujan J, Tebar FJ, Zamora S. Relationship between fat cell size and number and fatty acid composition in adipose tissue from different fat depots in overweight/ obese humans. Int J Obes (Lond) 2006;30:899-905.

84. Esposito K, Pontillo A, Di Palo C, Giugliano G, Masella M, Marfella R, Giugliano D. Effect of weight loss and lifestyle changes on vascular inflammatory markers in obese women: a randomized trial. JAMA 2003;289:1799-804.

85. Clément K, Viguerie N, Poitou C, Carette C, Pelloux V, Curat CA. Weight loss regulates inflammation-related genes in white adipose tissue of obese subjects. FASEB J 2004;18:1657-69.

86. Hartman H, Abdulla A, Awla D. P-selectin mediates neutrophil rolling and recruitment in acute pancreatitis. Br J Surg 2012;99:246-55.

87. Dominguez H, Storgaard H, Rask-Madsen C, Steffen Hermann T, Ihlemann N. Metabolic and vascular effects of tumor necrosis factor-alpha blockade with etanercept in obese patients with type 2 diabetes. J Vasc Res 2005;42:517-25.

88. Stanley TL, Zanni MV, Johnsen S, Rasheed S, Makimura H. TNF- a antagonism with etanercept decreases glucose and increases the proportion of high molecular weight adiponectin in obese subjects with features of the metabolic syndrome. J Clin Endocrinol Metab 2011;96:E146-50.

89. Mendoza-Núñez VM, García-Sánchez A, Sánchez-Rodríguez M, Galván-Duarte RE, Fonseca-Yerena ME. Overweight, waist circumference, age, gender, and insulin resistance as risk factors for hyperleptinemia. Obes Res 2002;10:253-9.

90. Heymsfield SB, Greenberg AS, Fujioka K, Dixon RM, Kushner R, Hunt 
T, Lubina JA, Patane J, Self B, Hunt P, McCamish M. Recombinant leptin for weight loss in obese and lean adults: a randomized, controlled, dose-escalation trial. JAMA 1999;282:1568-75.

91. Funcke JB, von Schnurbein J, Lennerz B, Lahr G, Debatin KM, FischerPosovszky P. Monogenic forms of childhood obesity due to mutations in the leptin gene. Mol Cell Pediatr 2014;1:1-8.

92. Wolfe BM, Kvach E, Eckel RH.Treatment of Obesity: Weight Loss and Bariatric Surgery. Circ Res 2016;118:1844-55.
93. Ertek S, Cicero A. Impact of physical activity on inflammation: effects on cardiovascular disease risk and other inflammatory conditions. Arch Med Sci 2012;8:794-804.

94. Sakurai T, Ogasawara J, Kizaki T, Sato S, Ishibashi Y, Takahashi M Kobayashi O, Oh-Ishi S, Nagasawa J, Takahashi K, Ishida H, Izawa $\mathrm{T}$, Ohno $\mathrm{H}$. The effects of exercise training on obesity-induced dysregulated expression of adipokines in white adipose tissue. Int J Endocrinol 2013;2013:1-28. 